UDC 37.025.7: 811.111

DOI https://doi.org/10.24919/2308-4863/37-3-34

Oksana TYMOFYEYEVA,

orcid.org/0000-0001-6645-5604

Candidate of Pedagogical Sciences, Associate Professor,

Associate Professor at the Humanities Department

Danube Institute

of the National University "Odesa Maritime Academy"

(Izmail, Odesa region, Ukraine) tymofoksana@gmail.com

Tetiana KONSTANTYNOVA, orcid.org/0000-0002-6374-343X Senior Lecturer at the Humanities Department

Danube Institute

of the National University "Odesa Maritime Academy"

(Izmail, Odesa region, Ukraine) tanyuscha29051979@gmail.com

\title{
THE STRATEGIES OF COLLABORATIVE LEARNING IN MARITIME ENGLISH
}

As maritime higher education institutions are systematically improving the level of teaching of knowledge, competency and skills of future marine officers in respond to the STCW and IMO model courses requirements, teamwork skills obviously, take a significant place in ship's crew training process. The process of future seafarers' professional training in maritime higher education institutions is systematically improved; language training occupies an important place while training. The result of teamwork is greater than the sum of individual results and most of our knowledge is created in society that is we learn from our immediate environment. Thus, the joint group environment is the natural way of learning. This article is aimed to search for the most efficient strategies of collaborative learning to implement acquired knowledge, competency and abilities in professional activities of the ship's crewmembers. The collaborative teaching strategies in higher education are aimed primarily at increasing students' own activity and their motivation to professional activities and life-long learning. They allow transferring from passive assimilation of knowledge to active application in model or real situations professional activity, which increases quality of training of future seafarers. The necessity of analyzing collaborative learning strategy should emphasize the special role and function of the lecturer as a teamwork leader and moderator. Possible application of collaborative strategies in the educational process of the maritime institution is under study. An important element of collaborative learning is the use of the interpersonal communication skills in a group by students/ cadets. In order for them to complete their tasks, everyone must communicate and work together. Collaborative learning methods stimulate cognition, motivate students and allow them in a team to learn and share large amounts of information. The article presents the examples of collaborative learning activities tasks in Maritime English classes. Particular attention is paid to the description of the specific technologies, techniques of teamwork in the form of pair and group work, analysis the possibility of their further application in the educational process.

Key words: collaborative learning, teamwork, maritime higher institutions, maritime English, future marine officers.

Оксана ТИМОФЕЕВА,

orcid.org/0000-0001-6645-5604

кандидат педагогічних наук, доиент, доиент кафедри гуманітарних дисциилін Дунайського інституту Національного університету «Одеська морська академія» (Ізмаїл, Одеська область, Україна) tymofoksana@gmail.com

Тетяна КОНСТАНТИНОВА, orcid.org/0000-0002-6374-343X старший викладач кафедри гуманітарних дисциилін Дунайського інституту

Наџіонального університету «Одеська морська академія» (Ізмаїл, Одеська область, Украӥна) tanyuscha29051979@gmail.com 


\title{
СТРАТЕГІЇ СПІЛЬНОГО НАВЧАННЯ У ВИКЛАДАННІ МОРСЬКОЇ АНГЛІЙСЬКОЇ МОВИ
}

\begin{abstract}
Оскільки морські заклади вищої освіти систематично вдосконалюють підготовку майбутніх моряків відповідно до вимог ПДМНВ та типових курсів Міжнародної морської організаџії, навички командної роботи займають значне місие у навчанні майбутніх офіцеерів торговельного флоту. Процес професійної підготовки майбутніх фахівиів морської галузі в морських вищих навчальних закладах систематично вдосконалюється, мовна підготовка займає вагоме місие. Результат колективної роботи перевищує суму індивідуальних результатів, $i$ більша частина наших знань створюється в суспільстві, тобто ми вчимось із нашого найближчого оточення. Отже, спільне середовище є природним способом навчання. Ця стаття спрямована на пошук найбільш ефективної стратегії спільного навчання для впровадження набутих знань, компетентності та здібностей у професійну діяльність майбутніх членів екіпажу судна. Стратегії спільного викладання у вищій освіті спрямовані насамперед на підвищення власної активності здобувачів та їх мотивацію до професійної діяльності. Вони дозволяють переходити від пасивного засвоєння знань до активного застосування в модельних або реальних ситуаціях професійної діяльності, щзо підвищує якість підготовки майбутніх моряків. Необхідність аналізу стратегій спільного навчання повинна підкреслювати особливу роль та функиії викладача як керівника командної роботи. Важливим елементом спільного навчання є використання здобувачами освіти своїх навичок міжособистісного спілкування в групі. Щоб студенти/курсанти виконали свою задачу, кожна людина повинна спілкуватися $і$ праиңювати спільно. Методи спільного навчання стимулюють пізнання, мотивують студентів та дозволяють їм у команді вчитися та ділитися великими обсягами інформаџії. Проаналізовано можливе застосування стратегій співпраці на заняттях з морської англійської. Наведені приклади завдань спільної навчальної діяльності. Особливу увагу приділено опису конкретних технологій, методів колективної роботи, аналізу можливості їх застосування в навчальному процесі в морському $3 В О$.
\end{abstract}

Ключові слова: спільне навчання, морські заклади вищої освіти, морська англійська, майбутні офіцери торгівельного флоту.

Stating the problem. The international shipping industry requires the competent merchant marine officers. The requirements for the future seafarers are stated by the STCW 78 with the Manila amendments 2010. The safe navigation, marine environmental preservation and handling of the cargo are possible in terms of implementation of teamwork skills of the seafarers during performing their duties and social life aboard the ship. The members of the ship's crew should cooperate constantly. The curriculum of all maritime high institutions is based upon the model course in Maritime English (IMO model course 3.17) which has been developed by the International maritime organization (IMO) together with the International Shipping Federation (ISF). Due to the requirements of this model course the Maritime English teaching process should rely on the communicative approach with its integral parts as contentbased instruction and task-based learning, teamwork, etc (Model Course, 2015). These ways of learning allow practicing a wide range of maritime topics as well as working out communication skills and thus cadets will attain the overall learning objective. The condition of fruitful outcome of the learning process is a variable collaboration of cadets.

Studied researches. The collaborative learning as the methodological term appeared in the 1960s and has been studied by a number of the researchers (B. L. Smith, J. T. MacGregor, 1992; J. Linden, G. Erkens, H. Schmidt, P. Renshaw, 2000; M. Laal, S. M. Ghodsi, 2012; E. F. Barkley, KP Cross, CH Major,
2014). The general methodical literature analysis and study on research issues showed that it has been investigated by the practitioners in some fields of English for Specific Purposes, for instance, of medical students (R. Nasr, J. Antoun, R. Sabra, N. Zgheib, 2016), shipboard engineers (R. Prasad, M. Baldauf, T. Nakazawa, 2011), of maritime security (E. Madariaga, L. Sánchez, P. Ortega, 2014). The empirical methods were used for achieving the objective of the article.

The purpose of the article. The primary aim of this article is to examine the most productive strategies of the collaborative learning for the sake of increasing of language competency of future merchant marine officers due to the lack of the studies of the strategies of the collaborative learning in Maritime English learning process.

Presentation of the main material. The ability of teamwork is defined as soft skills. These skills are essential for all marine officers despite the ship's department they belong to. The practitioners point out that in the process of cooperation and collaboration when we achieve success together and can estimate the value of others then we gain respectfulness. It will lead to the development of conflict management, reliability and active listening, which are the parts of teamwork skills. One of the productive ways of gaining the experience of teamwork and cooperation is the strategies of collaborative learning at Maritime English teaching process.

The word "collaborative" means shared, united. This learning views knowledge as a consensus that 
people construct in the process of communication. This strategy is based on the concept of knowledge management. The collaborative learning is traditionally defined as the educational approach of enhancing learning through cooperation. The social cultural theory affects vastly the performance of this approach, as this theory of L. Vygotsky concerns four aspects of cognitive development, namely mind, tools, Zone of Proximal Development (ZPD) and community of practice. The researchers identify the notion "community of practice" as a group of people who are recognized as having a special expertise and goals in some area of significant practice (Nuthall, 1997). The idea of community practice and benefits of social interaction creates the dialogical educational environment, which facilitates the learning process. Some of the characteristics of the approach are crucial for the learning outcomes of MET. Firstly, the cadets and the learning process itself are the goal of the classes. Secondly, cadets have the opportunity to choose or change the roles during the class activities. They are given free practice in most cases and the right to choose the group for the task. The drills are no longer seen to be effective way of gaining the knowledge or experience. Practice with other participants, support and sharing is the tenet of the learning process. The free choice or opportunity to choose improves the motivation of the cadets as well as their learning autonomy. They train own social and cognitive skills as a secondary gain of the learning process is performed (Figueiredo, 2008).

Collaboration emphasizes teamwork. Strategies of collaborative learning can be seen more than a kind of personal philosophy, not just teaching technique. At the heart of collaborative learning is a basement formed on cooperation of group members. Collaborative learning develops and coordinates a variety of skills and integrates them into competencies. Formation of competencies is associated with involvement in problem solving. The competencies need growing, and knowledge is lost in case of not being used. Therefore, knowledge as a process of increasing competencies is a strategic asset. Collaborative learning strategies include models of the knowledge creation process. Human knowledge expands through social interaction between hidden and open forms of knowledge. They interact and move from one form into another in the process of a person's creative activity and in learning stimulates creativity. The learning process is holistic, but at the same time, it consists of several subprocesses:

- transition into hidden knowledge (socialization is a process of exchange of experience, during which hidden knowledge such as mental models and technical skills is formed);

- transition of hidden knowledge into explicit knowledge; formation process during which hidden knowledge becomes apparent becoming the form of metaphors, analogies, principles, hypotheses or models, their combinations;

- transition into explicit knowledge, which includes combining different fragments of explicit knowledge;

- absorption is the process of introducing explicit knowledge into hidden knowledge, which is very closely related to "learning-in-process".

Such understanding of the essence and the structure of the educational strategy sets the formats of collaborative learning, such as group projects, class team projects, networking, etc.

The collaborative learning involves pair work and group work. The learning process and objectives of the activity can vary the number of the group mates. However, the number of participants does not essentially influence the outcome. During pair or group work as a form of collaborative approach the cadets have the opportunity of bearing responsibility for own study and results of their work. Moreover, such kind of collaborative work requires the sharing of knowledge and skills between the participants, they can assist in finding the solutions and assess the results with the peers, whereas the teacher's role is only to monitor. The development of linguistic competence along with the increasing the level of content knowledge are usually provoked during this kind of classroom activity (Goodsell and others, 1992).

The advantages of the collaborative learning in the field of linguistic knowledge should be mentioned: 1) the fluency is highly enhanced in the course of freer practice as well as the active listening skills, namely paraphrasing, clarification and feedback are being trained by the nature of the speech;2) the collaboration activities expose the gasps in language knowledge and skills of the cadets; 3 ) as they have the choice of activity and participants, the motivation for further learning increases gradually; 4) the freer practice implies the active productive skills of the English language and collaboration improves the performance of language skills significantly.

The collaboration means the teamwork. It gives cadets the basis for mutual support in achieving the learning outcomes. The level of anxiety for the language level usually reduces when the cadets collaborating with peers. The shame for some mistake or language barrier becomes less when they work and assess one another. While working together the cadets discover the diversity in the opinions and ways of 
solving the problems as well as in their language levels. These collaborative activities show the ways of considering and respecting the contribution of every participant. They are united by one goal, finding the proper solution to the given question. During the activities they can change the roles or even swap for some activity in order to obtain different experience. Such kind of cooperation and collaboration teach the cadets to respect, to deal with the tolerance and to consider diverse point of view. These skills are crucial for efficient work aboard the ship.

When analyzing a collaborative learning strategy, it should be emphasized about the special role and function of the lecturer or teacher. While collaboration the cadets can lack some language aspects or finding and correction of the mistakes. In this case they rely on the teacher. He/she takes the position of a leader in group work, or better to say moderator. The term "moderator" means someone who tries to help other people, come to an agreement; someone who makes certain afford that a formal discussion happens without problems and follows the rules (Cambridge dictionary). Nowadays moderation is determined as the technique of organizing collaboration, enabling group work becomes more focused and structured. Moderation is based on the use of techniques to help organize group work, and leading the cadets to decision-making through the implementation potential opportunities of the group as a whole and each of the participants separately (Hipkins, Robertson, 2011). The procedure of moderation involves the implementation a number of conditions: the size of the group for joint training - from 4 to 12 persons; neutral position of the moderator; a room that allows participants in the process freely move around, and at the same time a good visual material (presentation, whiteboard, video material, etc.); mandatory feedback from the group. The content of the moderator's activity differs from traditional activities of the lecturer. Moderation situation is not suggesting "podium" (lectern and board), "monologue" teacher, emphasis on the discipline of students, etc. During moderation of group work, joint development and training both the cadets and the moderator himself occurs. Authority of the moderator comes in the course of confirming a reasonable forecasting group work, applying deliberate technologies solving a group problem, setting and solving well-reasoned questions in a democratic learning environment. The moderator is the authority of the process, not the content. So he should have a high level of social competence: he should easily establish social contacts, take into account distribution of social roles in the group, understand the group dynamics, to manage the process of interper- sonal interaction. The moderator supports the group by organizing a reasonable purposeful behavior in it. Participants in joint training are to understand clearly the purpose of the activity offered by the moderator. It allows avoiding the misconception that the moderator manipulates the behavior of the group. While organization of the process co-learning moderator plays the role of a kind "catalyst" of group communication. The basic structure of moderation includes the following components: centering, collecting ideas, ranking, project work, formulation of an action plan.

The collaborative learning activities should include at least three stages regardless the time available in the classroom and task:

1. The moderator introduces the task and nominates the groups or pairs. The cadets have the right to change the peers.

2. The cadets are given sufficient time for task performance. If they lack knowledge or doubts arise the teacher assists them.

3. The last step is debriefing, summarizing and feedback.

"Brain storming" is the initial method of group work moderation. Due to the brainstorming, significant ideas can be quickly described and imagined preconditions for deepening and further development. Brainstorming provides the joint determination and prioritization, and leads to the conditions of preparing and holding the further course of the class or activity. The options for brainstorming are as follows: 1 . In turn. Instruction: Express the idea in turn. If there is no idea - say, "pass". There is no need to prove the idea. The group selects and presents $2-3$ the most successful ideas. 2. Free form. You can express an idea without waiting in line. The idea of a neighbour can be developed. The group selects and presents $2-3$ most successful ideas. 3. Own ideas. 3 minutes is given in complete silence to record own ideas as to the topic or problem. Next step is to discuss them with the group. 4. "Crazy" ideas. It is possible to express an idea, using any of the previous forms; the main thing is that it should be extraordinary. The group chooses and presents 2-3 most successful ideas.

"Shot-long" is one of the most suitable for Maritime English classes. In pair, one asks a question to the topic under discussion and it is necessary to give the short answer to this question and then the expanded answer using correct grammatical structures.

"Think in pairs". Moderator allows cadets/students to consider the set question or problem first individually (e.g. the fact of collision or malfunction of machinery). Then group members search for a solution by writing down opinions or just thinking (taking into account maritime conventions or manu- 
als for machinery operating). At the end, allotted time the cadet/student in a pair expresses his ideas and then listens to your partner's ideas. After discussion of the issue in pairs, the moderator suggests to express a jointly formulated answer according to the maritime rules and regulations for the seafarers.

"Mutual learning". We are talking about a joint material learning technique that allows cadets to build a pair dialogue concerning the given content. Members of the groups one by one present the topic and ask each other questions, receiving immediate feedback (e.g. types of buoyage systems, advantages of types of scavenging). Such interaction allows cadets to use important development techniques thinking, such as explanations, doubting, predicting and systematization. This is the case way through which cadets or student can learn effectively from each other.

"Spider Web Discussion". Basically, it is a student-centered discussion on a particular topic, question, or text (Giamellaro and others, 2019). While cadets are discussing the topic, the teacher is still the referee and master of knowledge, offering up the right question at the right moment, redirecting the conversation, correcting misunderstandings, and ensuring that cadets are being civil to one another. In Spider Web Discussion, the teacher is largely silent. The teacher has a blank note on which takes notes about their discussion. It is useful to stop the conversation midway to ask students how the web is forming and what could be done to improve it. After the discussion, it is imperative to give cadets time to evaluate the web, to identify particularly important moments in the conversation, in both discourse and in making sense of the science content.

For short time period, the activity of jigsaw type advantages as well as Fishbowl debate. The cadets are divided into groups of three or four, the roles are nominated, i.e. someone is pro the topic, another is contra it. The rest cadets are taking notes, like judges counting the score for every convincing argument. Then the judges of the group summarize the results and share the best or convincing concepts.

The task "Think-Pair-Share" requires some prior work and is also valuable for collaboration. The cadets prepare their response / attitude / ideas to the given question (text, video, talk) in advance (Think), then present them to the partner, may be with additional explanation (Pair), the last step they swap the pair partners and share opinions they heard (Share). The completion of the collaboration is group briefing and conclusions. The collaboration at the final stage represents the dynamic speaking activities for all cadets. It can provoke further discussion with the widening the initial task.
The long-term collaborative activities are case study, problem-solving tasks. The case method initially involves the use the surrounding life as a laboratory in which there is the process of cognition. The relevance of the introduction of the case-study method into the practice of higher professional education should be assessed as a method not limited to the tasks of obtaining an unambiguous answer, memorizing ready-made knowledge and forming a minimum of basic practical skills. This method is designed to motivate an individual search for answers with varying degrees of truth, to develop knowledge through immersion in the co-creation of all participants in educational activities, the development of a system of values, attitudes, a kind of attitude and awareness of oneself in the realities of the surrounding world.

There exist different approaches of using cases in educational process, it can be noted that the purpose of the case learning is most often viewed through the creation of conditions, with which learners independently and willingly acquire missing knowledge from different sources; learn to use acquired knowledge to address cognitive and practical tasks; obtain communication skills, working in different groups; develop their research skills (ability to identify problems, collect information, observation, experiment, analysis, construction hypotheses, generalizations); develop critical thinking skills. The main ideas of case-based learning are as follows: an activity that is chosen freely is performed with great enthusiasm; work on the case is built in line with the studied material, but goes beyond it; the educational process is not built in the logic of the educational subject, but in the logic of activity that has a personal meaning for students, which increases their learning motivation; deep, conscious assimilation of basic knowledge is provided for account of their universal use in different situations; the case learning is never one-sided, important and side information obtained during the development of the project. The case-based learning is based on consistent implementation of complex educational cases with information pauses for mastering basic theoretical knowledge. There is a certain scheme for working on a case, in the most general form, it can be represented as follows: a case initiative appears (it is best if it is given by the cadets, but at first the idea can come from teacher), project participants take up the project initiative, develop it, organize activities and inform each other and other stakeholders on the progress of work, everything is completed in the form of presentation of the project and reflection. We can find various classifications of the cases (Swain; 1995) but the structure of the case is mostly like this: 
1. Introduction (case hero, story, time of action)

2. The main part (the main body of information, internal intrigue, problem)

3. The final part (the situation may "hang", requires an appropriate solution)

4. Questions to the case

5. Appendix (additional information to the case: tables, statistics, additional details)

6. Conclusion (brief description of a possible solution)

7. Methodological recommendations for the analysis of the case (the author's approach to solving the case.

The problem solving tasks involve motives and impulses. The human being nature is interested in any kind of question or problem and way to solve it. The cadets may use own experience for finding the solution and the motivation is arisen. However, the problem presents a king of obstacle and solving it will release the inner pressure of a person and gain the required knowledge. The steps of this kind of activity are as follows:

1. Pre-solving (stating the problem, organizing the collaborative work)

2. Solving stage (collecting the data, studying the content, developing the action plan, searching for evidences, finding the decision)
3. Post-solving (sharing the solution, discussion and assessment)

J. V. Thomas (Thomas, 2000) states that problem solving tasks should be chosen in favor of producing gains in general academic achievement and for developing lower-level cognitive skills in traditional subject matter areas This method allows the cadets to improve their skills in searching the data, make them aware of different strategies for solving the problem, implementing these strategies accurately and proving skills.

Conclusions. The collaborative learning process is student (cadet)-centered with the corresponding sharing of responsibilities and assuming the results. The collaboration allows the cadets discovering another point of view, widening the awareness of the issue. Furthermore, the participants present their ideas spontaneously, respond the partners and find mutual solutions under the terms closely resembling real life communication. The range of questions and contexts for collaborative tasks leads to developing and training communicative, problem solving and reasoning skills of the cadets. The strategies based on the teamwork will lead to developing the proficiency in the English language required by the STCW Code, and will give the cadet/student wide-ranging opportunities to practice communicating in English for both maritime and general purposes at different language levels.

\section{BIBLIOGRAPHY}

1. Model Course 3.17. Maritime English, International Maritime Organization. London, 2015. 228 p.

2. Nuthall G. Understanding student thinking and learning in the classroom. In B. J. Biddle, T. C. Good \& I. Goodson (Eds.), The International Handbook of Teachers and Teaching. Dortrecht : Kluwer Academic publishers, 1997. P. 681-768.

3. Figueiredo F. J. The influences of collaboration on the learning of a foreign language. Moara, 2008. P. 117-134. URL: https://www.periodicos.ufpa.br/index.php/moara/article/view/3379/3287

4. Collaborative Learning: A Sourcebook for Higher Education / Goodsell Anne S. et al. Pennsylvania State University, 1992. $175 \mathrm{p}$.

5. URL: https://dictionary.cambridge.org/ru/словарь/английский/moderator

6. Hipkins R., Robertson S. Moderation and Teacher Learning. New Zealand Council for Educational Research Wellington, $2011.38 \mathrm{p}$.

7. A Web of Ideas: Fostering scientific discourse with spider web discussions. Science teacher / M. Giamellaro et al. 2019. P. 48-54. URL: https://www.researchgate.net/publication/332247492_A_Web_of_Ideas_Fostering_scientific_discourse_with_spider_web_discussions

8. $\overline{\text { Swain }}$ M. Three functions of output in second language learning / Cook G., Seidhofer B. Principle \& Practice in Applied Linguistics. Oxford : Oxford University Press, 1995. P. 125-144.

9. Thomas J. W. A Review of Research on Project-Based Learning. 2000. URL: http://www.bobpearlman.org/BestPractices/PBL_Research.pdf

\section{REFERENCES}

1. Model Course 3.17. Maritime English, International Maritime Organization, London, 2015. 228 pp

2. Nuthall, G. Understanding student thinking and learning in the classroom. In B. J. Biddle, T. C. Good \& I. Goodson (Eds.), The International Handbook of Teachers and Teaching, Dortrecht: Kluwer Academic publishers, 1997. pp. 681-768.

3. Figueiredo F. J. The influences of collaboration on the learning of a foreign language: Moara, 2008. pp. 117-134. Retrieved from https://www.periodicos.ufpa.br/index.php/moara/article/view/3379/3287

4. Collaborative Learning: A Sourcebook for Higher Education / Goodsell Anne S., and others. Pennsylvania State University, 1992. $175 \mathrm{p}$.

5. https://dictionary.cambridge.org/ru/словарь/английский/moderator

6. R. Hipkins, S. Robertson Moderation and Teacher Learning. New Zealand Council for Educational Research Wellington, 2011, 38p. 
7. Giamellaro, Michael \& Blackburn, Jackson \& Honea, Molly \& Laplante, Jacob.. A Web of Ideas: Fostering scientific discourse with spider web discussions. Science teacher, 2019. pp. 48-54. Retrieved from https://www.researchgate.net/ publication/332247492_A_Web_of_Ideas_Fostering_scientific_discourse_with_spider_web_discussions

8. Swain M. Three functions of output in second language learning / Cook G., Seidhofer B. Principle \& Practice in Applied Linguistics. Oxford: Oxford University Press, 1995. pp. 125-144

9. Thomas, J.W. A Review of Research on Project-Based Learning. 2000. Retrieved from http://www.bobpearlman.org/ BestPractices/PBL_Research.pdf 